原著

\title{
脳主幹動脈閉塞または狭窄症における脳機能の性状：
}

脳波による機能回復性または hemodynamic crisis の可能性判定

\author{
鈴木 明文, 安井信之
}

\section{Detection of Functional Reversibility and Hemodynamic Crisis in Cerebral Ischemia by the EEG Study}

\author{
Akifumi Suzuki, M.D., and Nobuyuki Yasui, M.D. \\ Department of Surgical Neurology, Research Institute for Brain and \\ Blood Vessels-Akita, Akita, Japan
}

Summary : The functional reversibility and the possibility of hemodynamic crisis were studied in 21 patients with stenoocclusive diseases in internal carotid artery or the trunk of middle cerebral artery. Those patients showed improvement or deterioration of EEGs under induced hypertension or hypotension. The induced hypertension increases the cerebral blood flow (CBF) in the dysautoregulatory area of ischemic brain. The induced hypotension decreased the CBF of patients who possess the possibility of hemodynamic crisis. Angiotensine ${ }^{\circledR}$ or dobutamine was administered intravenously for the induced hypertension. Alfonad ${ }^{\circledR}$ was administered intravenously for the induced hypotension. The maximum range of induced hypertension was $+30 \mathrm{mmHg}$, and that of induced hypotension was $-10 \mathrm{mmHg}$ by mean blood pressure. EEGs were recorded from 21 points on the scalp according to $10 / 20$ international method, and analyzed by interval histograms and amplitude histograms automatically. From the interval histogram, \% time of each frequency band was calculated. In the present study, the change of $\%$ time and amplitude was evaluated statistically by t-test.

EEGs of 9 patients improved under induced hypertension. In those patients, the brain function was considered to improve by the increase of $\mathrm{CBF}$. Seven of those patients underwent bypass surgery, and all of them improved clinically. However, 2 of the surgical patients suffered reoccurrence cerebral ischemia due to the embolic process. Two other patients were treated conservatively. One improved after spontaneous recanalization, but the other did not improve.

EEGs of 12 patients deteriorated under induced hypotension. In those patients, the brain function was considered to deteriorate subclinically due to hemodynamic crisis. Eight of those patients underwent bypass surgery, and further occurrence of cerebral ischemia have been prevented postoperatively. Four other patients were treated conservatively, and one patient suffered the reattack of cerebral ischemia. Both surgical and conservative patients have been administered aspirin.

Therefore, the EEG analysis under the blood pressure change is useful to detect the functional reversibility and the possibility of hemodynamic crisis in patients of cerebral ischemia. To select suitable candidates for bypass surgery, those functional studies are necessary.
Key words :

- cerebral ischemia

- functional reversibility

- hemodynamic crisis

- EEG

- blood pressure change

秋田県立脳血管研究センター 脳神経外科(受稿日 1991.8.15)〔連絡先：テ010 秋田市千秋久保田町6-10 秋田県立脳血管研究 センター 脳神経外科 鈴木明文] 


\section{はじめに}

脳主幹動脈の閉塞または高度狭窄症に対する血行再建術 の適応について我々は脳循環代謝とともに脳機能の性状に も注目して脳波や誘発電位による検討を行ってきた(1)2)4)5) 7) 10)14). 血行再建術は脳虚血により障害された脳機能を改 善する目的と hemodynamic crisisにより生じる脳虚血発 作を防止する目的がある。 そして，手術適応の決定に際し ては血行再建による脳血流の改善が脳機能改善や脳虚血発 作の防止をもたらすか否かを知ることが必要である．我々 はそのため脳血流を変えうる薬物の負荷を行い, 脳機能に 対する効果を脳波や誘発電位で検討してきた。今回はその ような負荷テストで脳波になんらかの変化がみられた症例 について転帚を含めて報告する。

\section{対象および方法}

対象は内頸動脈または中大脳動脈主幹部に閉塞や高度狭 窄を認め, 以下に述べる負荷テストで脳波の有意な変化を きたした 21 例である (Table 1). 男 18 例, 女 3 例で年齢 は4 41 から 78 歳 (56 土9 歳)であった。臨床型は重度の片麻 痺や全失語あるいは意識障害を呈した major stroke が 6 例, 片麻痺や失語症が軽度で意識も清明である minor stroke が 9 例, 回復性虚血性神経脱落 (RIND) が 4 例, 過性脳虚血発作 (TIA) が 2 例である。このうち 15 例で頭
蓋内外血管吻合術 (以下バイパス術)が行われた。臨床的な 経過観察期間は平均約 6 年であり, バイパス術による臨床 的改善度は術後 1 力月目に判定した. 手術の有無にかかわ らずアスピリンまたはチクロピジンを投与して経過観察を 行った.

脳波は 10/20 国際法に従って頭皮上 16 または 21 部位よ り再耳氺を基準にして記録した。周波数特性は $0.3 \sim 30$ $\mathrm{Hz}$ である.

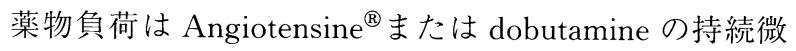
量静注による血圧上昇措置と trimetaphan camsilate $\left(\right.$ Alfonad $\left.^{\circledR}\right)$ の持続微量静注による血圧下降措置で行った。 前者は脳虚血のために脳循環自動調節能の障害 (dysautoregulation)に陥った領域で脳血流を増加させることを目的 とし, 後者は高度狭窄部の通過血流量や血管閉塞例での側 副血行を減少させることを目的とした．特に後者の血圧下 降措置は臨床的な脳虚血症状を生じる危険性があり厳重な 監視のもとで行った．血圧上昇措置はバイパス血流による 脳機能改善の可能性を, 血圧下降措置は hemodynamic crisisによる脳機能悪化の可能性を検討する方法であり， 症例毎にこれらの方法を選択した. 血圧変動の範囲は安静 臥床時の血圧を基準にして，血圧上昇措置は平均血圧で+ $30 \mathrm{mmHg}$ を上限とし, 最高血圧では $180 \mathrm{mmHg}$ 以内の範 囲とした。血圧下降措置はー $10 \mathrm{mmHg}$ を下限とし，最高 血圧では $90 \mathrm{mmHg}$ 以上の範囲で行った。なお，安静臥床

Table 1 Case summary

\begin{tabular}{|c|c|c|c|c|c|c|c|c|}
\hline No & Age & Sex & Angiography & Stroke & Bypass & EEG study & Postop. state & Reattack \\
\hline 1 & 60 & M & L IC S & Major & $14 d$ & I (11d) & Improved & - \\
\hline 2 & 58 & M & $\mathrm{RMCO}$ & Major & $2 d$ & $1(2 d)$ & Improved & $+($ emboli) \\
\hline 3 & 67 & $\mathrm{~F}$ & $R I C \& M C O$ & Minor & $17 d$ & $I(14 d)$ & Improved & - \\
\hline 4 & 52 & M & $\mathrm{RICO}$ & Minor & $2 d$ & $I(1 d)$ & Improved & - \\
\hline 5 & 56 & M & RICO & Minor & $74 \mathrm{~d}$ & I (69 d) & Improved & - \\
\hline 6 & 55 & $\mathrm{~F}$ & $\mathrm{RICO}$ & RIND & $47 d$ & I (45 d) & Improved (EEG) & + (emboli) \\
\hline 7 & 51 & M & RICO & RIND & $53 d$ & I (52 d) & Improved (EEG) & - \\
\hline 8 & 53 & M & LICO & Major & - & $I(0 d)$ & $\begin{array}{l}\text { (Improved by } \\
\text { recanali..) }\end{array}$ & - \\
\hline 9 & 61 & M & L MC O & Major & - & I $(1 d)$ & (Unchanged) & - \\
\hline 10 & 65 & M & $\mathrm{RICO}$ & Major & $25 d$ & $w(7 d)$ & Unchanged & - \\
\hline 11 & 61 & M & L MC O & Minor & $4 \mathrm{~m}$ & $W(3 m)$ & Improved & - \\
\hline 12 & 46 & M & $\mathrm{BICO}$ & Minor & $\begin{array}{l}\mathrm{L}: 30 \mathrm{~d} \\
\mathrm{R}: 60 \mathrm{~d}\end{array}$ & $W(28 d)$ & Improved & - \\
\hline 13 & 41 & M & L MC O & Minor & $29 \mathrm{~d}$ & $W(24 d)$ & Unchanged & - \\
\hline 14 & 47 & M & L MC O & Minor & $44 m$ & W (44 m) & Unchanged & - \\
\hline 15 & 59 & M & RIC S & RIND & $22 d$ & $W(9 d)$ & Unchanged & - \\
\hline 16 & 62 & M & L ICO & RIND & $3 m$ & $W(54 d)$ & Unchanged & - \\
\hline 17 & 55 & M & $\mathrm{RMCO}$ & TIA & $44 d$ & $W(34 d)$ & Unchanged & - \\
\hline 18 & 66 & $F$ & $\mathrm{RMCO}$ & Major & - & $W(0 d)$ & (Unchanged) & - \\
\hline 19 & 42 & M & L MCO & Minor & - & $W(9 m)$ & (Unchanged) & - \\
\hline 20 & 53 & M & B IC O & Minor & - & $W(32 d)$ & (Unchanged) & - \\
\hline 21 & 78 & M & RICO & TIA & - & $W(1 d)$ & (Unchanged) & $+($ died $)$ \\
\hline
\end{tabular}

L: Left, R: Right, IC: internal carotid antery, MC: the trunk of middle cerebral artery, O: Occlusion, S: severe stenosis, d: day(s) after onset, m: Month(s) after onset, I: improved, W: worsened, (EEG): only EEGs were improved, Postop. state: the clinical result within one month after bypass surgery, or that of one month after the EEG study in non-surgical cases, recanali.: spontaneous recanalization. 


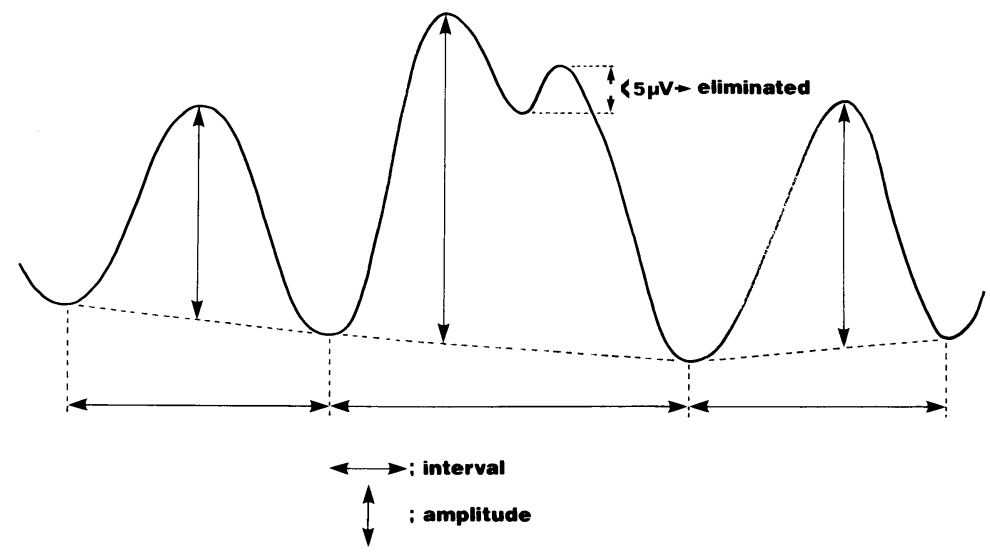

Fig. 1 The method of EEG analysis. Firstly, peaks of the EEG wave were detected. Secondly, a wave with peak-to-peak amplitude being less than 5 microvolt was regarded as an artifact and eliminated. Thirdly, the interval and amplitude of each EEG wave were measured. Then, the interval histogram based on the number of waves and amplitude histogram were made. The interval of EEG waves was represented as \% time of each frequency band.

時の平均血圧が $120 \mathrm{mmHg}$ 以上あるいは最高血圧が 160 $\mathrm{mmHg}$ の場合は血圧上昇措置は行わず，平均血圧が 70 $\mathrm{mmHg}$ 以下あるいは最高血圧が $110 \mathrm{mmHg}$ 以下の場合は 血圧下降措置を行わないことを原則とした。

脳波は我々の方法で分析して各周波数带域毎の出現率 (\% time) と平均振幅值を求め, 薬物負荷前と負荷中の記録 を統計学的に比較検討した，脳波の分析方法を簡単に紹介 すると，ある条件下の記録から artifactのない部分を 10 秒間ずつ 6 力所選ぶ. それぞれについて, Fig. 1 に示し たように波の変曲点を検出して周期と振幅值を求める。 そ の際，振幅が $5 \mu \mathrm{V}$ 以下の波は artifact とみなして除外し た。 そして各周波数帯域毎に周期と振幅値の合計值を求め る. 周期については記録時間すなわち 10 秒でその合計值 を除して各周波数帯域の時間的割合を出現率 (\% time) とし て算出する．振幅值については波の個数でその合計值を除 して各周波数帯域の平均振幅值を算出する。これにより頭 皮上の各電極点である周波数帯域の出現率および平均振幅 值がひとつの条件下でそれぞれ 6 個得られることになる. 次いで, 各条件下で得られた 6 個の值について $t$ 検定によ り変化の有意性を検討する。これらの処理により, 薬物負 荷においてどの電極点でどのような変化が脳波上有意にみ られたかを知ることができる。

\section{症例}

上述した脳波薬物負荷テストの実際を代表的な症例で紹 介する.

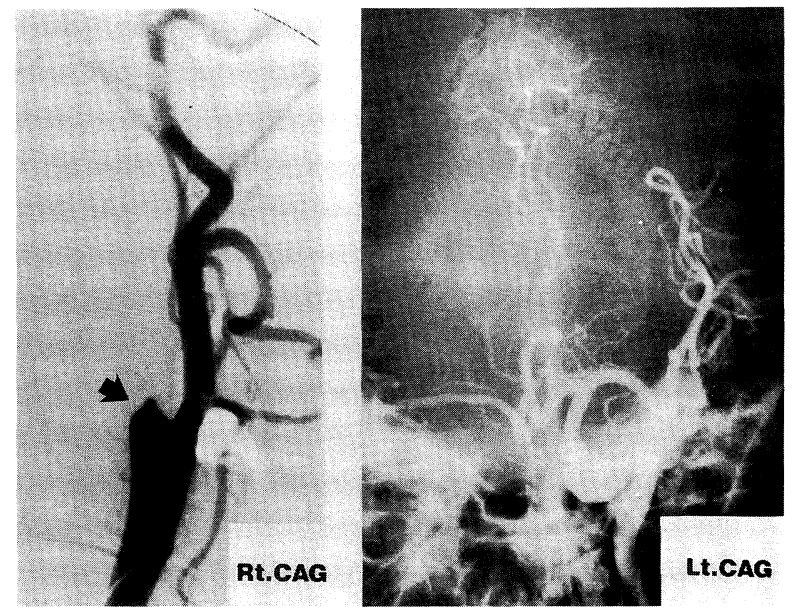

Fig. 2 CAGs in Case 5. The arrow indicates right internal carotid artery occlusion.

<症例 5> 56 歳, 男性. 記憶障害, 失見当識, 左片麻痺 で発症し当センターに入院した。脳血管撮影で右内頸動脈 閉塞 (Fig. 2) と診断されたが，高圧酸素療法などで症状が 改善したためいったん退院しアスピリン療法で経過観察と なった.しかし左脱力の TIA を繰り返し再入院したが, すでに構音障害，記憶障害，失見当識，軽度の左片麻痺を 明らかに認めた。初回発作から 69 日目に脳波の負荷テス トを行った。薬物負荷は dobutamine $5 \mu \mathrm{g} / \mathrm{kg} / \mathrm{min} の$ 持続 静注とした。負荷前の平均血圧は $113 \mathrm{mmHg}$ であり，負 荷後 $133 \mathrm{mmHg}$ に上昇した。Fig. 3, 4 に出現率と振幅値 に関する脳波卜ポグラフィーを示す。これらはそれぞれの 条件下でサンプリングした 6 区間の脳波から得られた值の 
A
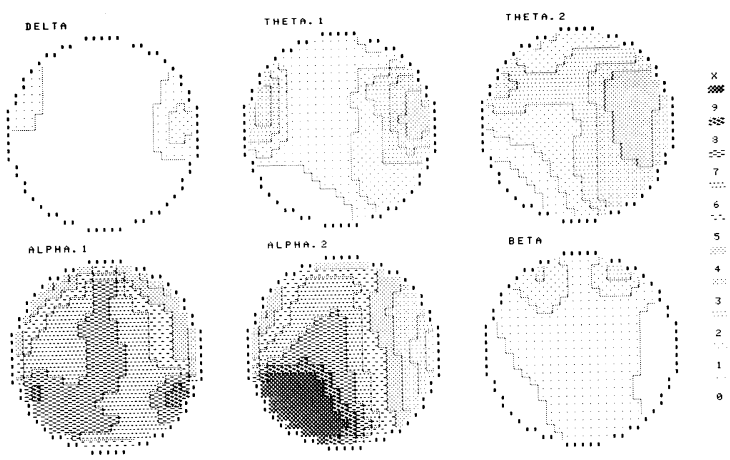

B

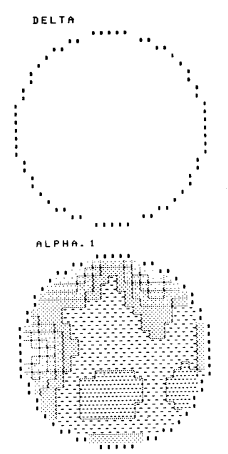

A
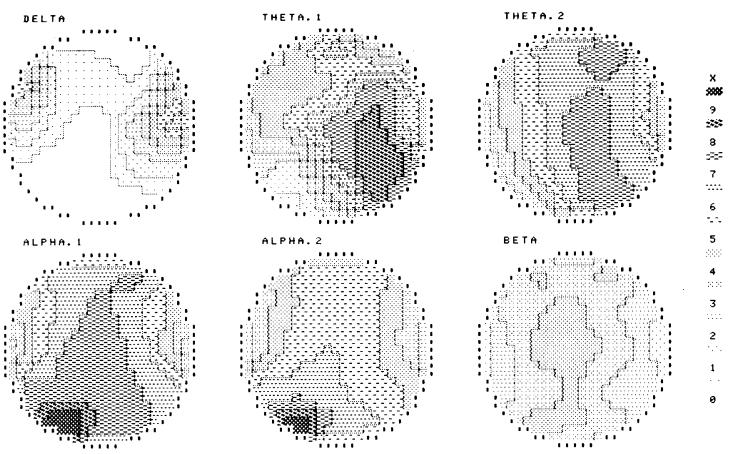

B

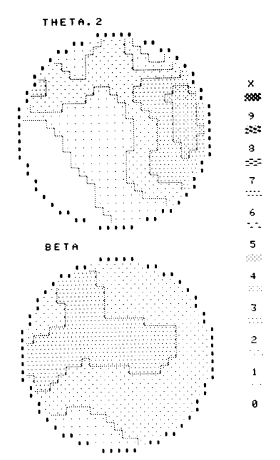

Fig. 3 The EEG topography of \% time in Case 5. A: Resting state. B: Induced hypertension. 4\%/step. Delta; $1-3 \mathrm{~Hz}$, Theta. $1 ; 4,5 \mathrm{~Hz}$, Theta. 2; 6, $7 \mathrm{~Hz}$, Alpha. 1; 8, $9 \mathrm{~Hz}$, Alpha. 2; 10-13 Hz, Beta; $14-17 \mathrm{~Hz}$.

平均值で作成したものである，血圧上昇後に徐波帯域の出 現率，振幅值がともに減少している.

Table 2, 3 に主な電極点における徐波帯域の統計学的な 結果を示す. Table 2 に示すように右半球の徐波出現率は 特に theta 波帯域で有意に減少した。しかし，振幅值は 4, $5 \mathrm{~Hz}$ の theta 1 帯域では減少したものの 6, $7 \mathrm{~Hz}$ の theta 2 帯域では有意に増加した. Table 3 に示すように左半球 でも特に theta 1 带域の出現率と振幅值は有意に減少した。 以上の結果より血圧上昇措置により脳血流が増加して脳機 能が改善したと考え, 初回発作から 74 日目に右浅側頭動 脈一中大脳動脈 (STA-MCA) 吻合術を行った. 術後症状の 改善が明らかで, 3.5 年経た現在神経学的に正常でありこ の間再発作も経験していない.

\section{結果}

21 症例の結果を Table 1 に示した.

\section{1. バイパス術施行例}

\section{1) 術前血圧上昇措置で脳波が改善した症例}

15 例でバイパス術を施行したが，術前の脳波負荷テス トにおいて 7 例で血圧上昇措置による脳波の改善がみられ
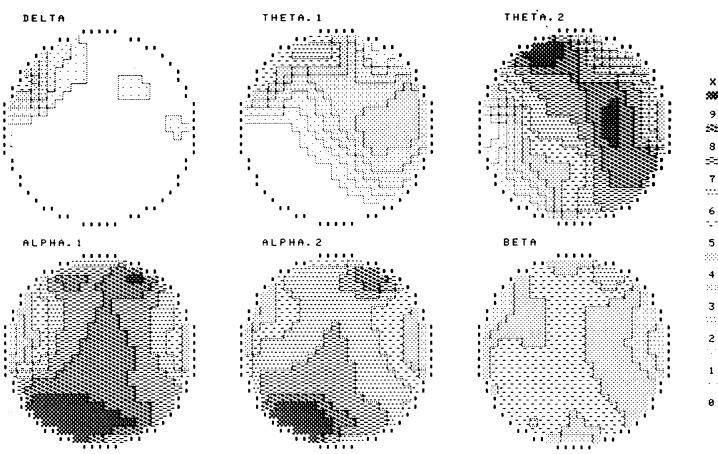

Fig. 4 The EEG topography of amplitude in Case 5. A: Resting state. B: Induced hypertension. 3 microvolt/step.
た.このうち major strokeは 3 例中 2 例で術後臨床的に も改善した。他 1 例は 2 日目の急性期にバイパス術を行い 術後いったんは臨床的に改善したが発症 7 日目に再開通に よる出血性梗塞のため再び悪化し, 結局術前と同じ状態に なった。経過中に心房細動がみられ塞栓症と考えられた症 例である. minor strokeは 2 例であったがいずれも術後臨 床的に改善した. RINDの 2 例では術前後ともに臨床症状 は問題なかったが, 術前にみられた脳波の徐波化は術後改 善した。ただし， 1 例は発症 64 力月目に再発作を生じて 死亡した.この症例も再発作時に心房細動がみられ塞栓症 による再発作と考えられた。

\section{2) 術前血圧下降措置で脳波が悪化した症例}

術前の血圧下降措置により 8 例が脳波の悪化を示した. major stroke 1 例, minor stoke 4 例, RIND 2 例, TIA 1 例である. 術後の再発作はいずれの症例においてもみられ ていない.ただ術後臨床的に改善したのは minor stroke の 2 例のみである.

\section{2. 保存的治療例}

急性期の血圧上昇措置で major stroke 2 例が脳波の改善
1) 血圧上昇措置で脳波が改善した症例 
Table 2 Results of statistical analysis of EEG changes in the right hemisphere of Case 5

\%time

\begin{tabular}{|c|c|c|c|c|c|c|c|c|c|}
\hline & \multicolumn{3}{|c|}{ Delta waves } & \multicolumn{3}{|c|}{ Theta 1 waves } & \multicolumn{3}{|c|}{ Theta 2 waves } \\
\hline & Rest & Hypertension & $t$-test & Rest & Hypertension & t-test & Rest & Hypertension & t-test \\
\hline $\mathrm{F}_{4}$ & $0.7 \pm 2.5$ & $0.4 \pm 1.7$ & $\mathrm{~ns}$ & $14.6 \pm 6.8$ & $2.5 \pm 4.1$ & $\downarrow \downarrow$ & $23.5 \pm 6.8$ & $15.9 \pm 5.5$ & $\downarrow \downarrow$ \\
\hline $\mathrm{C}_{4}$ & $2.5 \pm 3.9$ & $0 \pm 0$ & $\downarrow$ & $10.1 \pm 5.6$ & $2.3 \pm 2.1$ & $\downarrow \downarrow$ & $20.8 \pm 4.7$ & $10.8 \pm 6.8$ & $\downarrow \downarrow$ \\
\hline $\mathrm{P}_{4}$ & $1.6 \pm 3.0$ & $0 \pm 0$ & ns & $12.2 \pm 6.8$ & $2.3 \pm 3.2$ & $\downarrow \downarrow$ & $19.7 \pm 4.1$ & $12.8 \pm 6.6$ & $\downarrow \downarrow$ \\
\hline $\mathrm{O}_{2}$ & $0 \pm 0$ & $0 \pm 0$ & ns & $8.9 \pm 7.0$ & $0.3 \pm 1.0$ & $\downarrow \downarrow$ & $20.2 \pm 4.6$ & $6.4 \pm 3.5$ & $\downarrow \downarrow$ \\
\hline$T_{4}$ & $10.7 \pm 7.6$ & $0.5 \pm 1.7$ & $\downarrow \downarrow$ & $25.9 \pm 9.5$ & $6.1 \pm 5.0$ & $\downarrow \downarrow$ & $20.0 \pm 8.6$ & $19.7 \pm 8.9$ & $\mathrm{~ns}$ \\
\hline
\end{tabular}

Amplitude

\begin{tabular}{|c|c|c|c|c|c|c|c|c|c|}
\hline & \multicolumn{3}{|c|}{ Delta waves } & \multicolumn{3}{|c|}{ Theta 1 waves } & \multicolumn{3}{|c|}{ Theta 2 waves } \\
\hline & Rest & Hypertension & t-test & Rest & Hypertension & t-test & Rest & Hypertension & $t$-test \\
\hline $\mathrm{F}_{4}$ & $2.9 \pm 10.1$ & $4.2 \pm 14.7$ & ns & $26.3 \pm 6.5$ & $12.0 \pm 15.3$ & $\downarrow \downarrow$ & $23.6 \pm 2.7$ & $29.2 \pm 3.9$ & $\uparrow \uparrow$ \\
\hline $\mathrm{C}_{4}$ & $12.0 \pm 17.9$ & \pm 0 & $\downarrow$ & $28.3 \pm 11.1$ & $18.3 \pm 16.7$ & ns & $23.8 \pm 3.5$ & $31.9 \pm 8.5$ & $\uparrow \uparrow$ \\
\hline $\mathrm{P}_{4}$ & $7.7 \pm 14.4$ & \pm 0 & ns & $30.4 \pm 6.4$ & $13.7 \pm 17.5$ & $\downarrow \downarrow$ & $23.8 \pm 2.3$ & $28.6 \pm 3.5$ & $\uparrow \uparrow$ \\
\hline $\mathrm{O}_{2}$ & $0 \pm 0$ & $0 \pm 0$ & ns & $27.7 \pm 12.0$ & $2.3 \pm 8.0$ & $\downarrow \downarrow$ & $26.9 \pm 3.1$ & $25.9 \pm 10.0$ & ns \\
\hline $\mathrm{T}_{4}$ & $23.9 \pm 14.4$ & $4.2 \pm 9.9$ & $\downarrow \downarrow$ & $18.4 \pm 2.1$ & $16.6 \pm 10.5$ & ns & $16.4 \pm 2.5$ & $20.0 \pm 2.3$ & $\uparrow \uparrow$ \\
\hline
\end{tabular}

mean \pm SD

$\downarrow$ : decreased significantly $(p<0.05) \quad \uparrow:$ increased significantly $(p<0.05)$

$\downarrow \downarrow$ : decreased significantly $(p<0.01) \quad . \quad \uparrow \uparrow:$ increased significantly $(p<0.01)$

ns : not significant

Table 3 Results of statistical analysis of EEG changes in the left hemisphere of Case 5

\%time

\begin{tabular}{|c|c|c|c|c|c|c|c|c|c|}
\hline & \multicolumn{3}{|c|}{ Delta waves } & \multicolumn{3}{|c|}{ Theta 1 waves } & \multicolumn{3}{|c|}{ Theta 2 waves } \\
\hline & Rest & Hypertension & t-test & Rest & Hypertension & t-test & Rest & Hypertension & t-test \\
\hline $\mathrm{F}_{3}$ & $1.1 \pm 2.7$ & $0.5 \pm 2.0$ & ns & $4.5 \pm 3.5$ & $0.9 \pm 1.8$ & $\downarrow \downarrow$ & $13.3 \pm 4.2$ & $8.8 \pm 7.6$ & ns \\
\hline $\mathrm{C}_{3}$ & $0.9 \pm 2.2$ & $0 \pm 0$ & ns & $5.8 \pm 3.4$ & $0.7 \pm 1.7$ & $\downarrow \downarrow$ & $10.3 \pm 6.4$ & $6.0 \pm 5.0$ & ns \\
\hline$P_{3}$ & $0 \pm 0$ & \pm 0 & ns & $3.7 \pm 5.8$ & $0 \pm 0$ & $\downarrow$ & $6.5 \pm 4.5$ & $3.9 \pm 3.1$ & ns \\
\hline$O_{1}$ & $0 \pm 0$ & $0 \pm 0$ & ns & $0.7 \pm 1.7$ & $0 \pm 0$ & ns & $2.7 \pm 4.5$ & $0.9 \pm 1.3$ & ns \\
\hline $\mathrm{T}_{3}$ & $4.1 \pm 4.3$ & $0 \pm 0$ & $\downarrow \downarrow$ & $17.7 \pm 8.8$ & $0 \pm 0$ & $\downarrow \downarrow$ & $10.6 \pm 5.8$ & $0 \pm 0$ & $\downarrow \downarrow$ \\
\hline
\end{tabular}

\section{Amplitude}

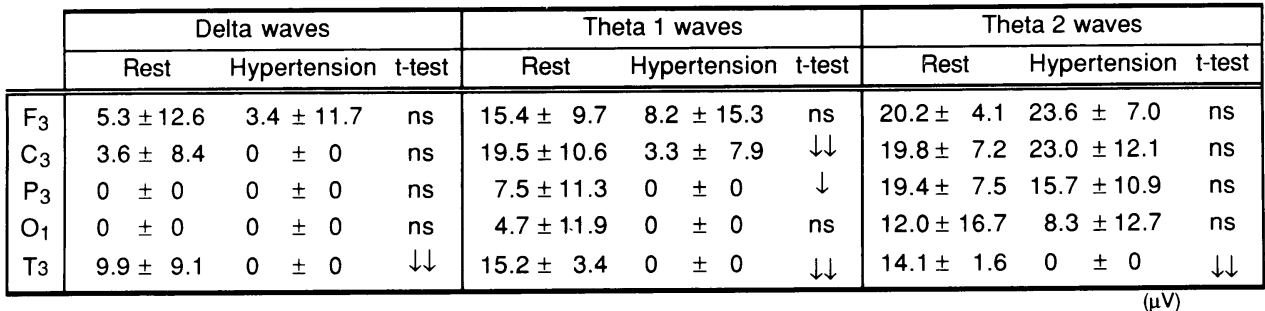

mean \pm SD

$\downarrow$ : decreased significantly $(p<0.05) \quad \uparrow:$ increased significantly $(p<0.05)$

$\downarrow \downarrow$ : decreased significantly $(p<0.01) \quad \uparrow \uparrow:$ increased significantly $(p<0.01)$

ns : not significant

を示した．うち 1 例は塞栓症でその後自然再開通し臨床的

に改善した。他 1 例は臨床的に不变のままであった。

\section{2）血圧下降措置で脳波が悪化した症例}

minor stroke 3 例と TIA 1 例である。このうち TIA 1

例は 4 年後に再発作を生じて major stroke となり死亡し

た. minor strokeの3 例には再発作がみられていない.

\section{考察}

Barnett らの国際共同研究では再発作予防を目的とした バイパス術の有効性が証明されなかった ${ }^{1112)}$. しかし, hemodynamic crisis か否かを判定するのは困難であったこ とからその可能性については考慮されなかった。また， 
stroke 発生率に関する研究であったためにバイパス術によ る症状改善については検討されなかった. バイパス術の適 応を決めるにあたりこれらの 2 点は重要であり, 何らかの 方法で検討しなければならない。

我々は以前から虚血脳の病態を脳機能の面から検討して きた 1)2445)7１0)14). 目的は妥当な治療法の選択基準, 特に バイパス術の適応決定であり, 方法は血圧变動に伴う脳波 や誘発電位の变化を分析することであった。我々の以前の 検討 $^{2)}$ や Schmiedek らの報告 ${ }^{3)}$ では stroke 例のほとんど が虚血巣の dysautoregulation を示している. 血圧上昇措 置はこの現象を利用した一種のシュミレーションテストで あり，バイパス術などの血行再建術で脳血流量を増加させ た場合の脳機能改善の可能性を術前に脳波や体性感覚誘発 電位 (SEP) で定量的に検討するものである，脳虚血発作の 再発が問題となる TIA のような症例では, 起立性低血圧 などの血圧下降に伴う脳虚血発作すなわち hemodynamic crisis の防止に血行再建術が考慮される。 そこで人為的な 血圧下降措置による subclinical なレベルでの脳機能悪化 の有無を脳波や SEP で評価し hemodynamic crisis の可能 性を検討した。以前は脳波の用手的周波数分析と SEP の $\mathrm{N}_{1}\left(\mathrm{~N}_{20}\right)$ 成分の分析を行っていた. 用手的周波数分析では 周期と振幅值を計測して, 周期から出現率 (\% time) を計算 して評価していた，その後医用コンピュータの発達により 容易にしかも頭皮上二次元表示 (脳波卜ポグラフィー)とし て脳波分析が可能となった ${ }^{13)}$. しかし，一般に広く応用 されている高速フーリ工变換 $(\mathrm{FFT})$ にるる周波数分析で は脳波の振幅值に関する情報しか得られず，用手法で分析 した出現率の結果に比べて変化を検出することが困難であ った，その理由のひとつとして頭皮上脳波は頭蓋骨などイ ンピーダンスの高い構造物を介して記録されるため皮質上 で記録される脳波に比べれば振幅值が相当減衰しており, 皮質上脳波がかなり変化しなければ頭皮上で検出し難いこ とが考えられた，その点周期は頭皮上脳波でも皮質上脳波 でも変わりなく，したがって変化を検出しやすいと考えら れる。ちなみに今回の対象例で振幅值に有意な変化がみら れたのは紹介した症例 5 のみであった。 そこで波形認識法 を用いた周波数分析で脳波の周期に関する情報も自動分析 できるようにした ${ }^{6) 89)}$. ところが，波形認識法における 脳波の認知基準には主観的な要素が含まれている。できる だけ客観的な評価を目指すことから現在は前述の我々の方 法により自動分析して周期から計算される出現率 (\% time) と振幅值に分けて評価している，また，脳波変化の程度も 客観的に評価するため $t$ 検定を用いて統計学的に分析して いる，一方，SEP の反映する脳機能は体性感覚系に限ら れていることや, 症例によっては末梢神経刺激のため安静 を保ち難くなるため現在はSEP を用いていない.
さて, 我々の結果では血圧上昇措置で脳波の改善が得ら れた stroke 例はバイパス術や急性期の自然再開通により 全例が臨床的に改善した。一方，保存的に経過をみた 1 例 は臨床的に改善はなかった。ただしバイパス術を施行した 1 例は塞栓症であり 7 日目の再開通で出血性梗塞をきたし 再び悪化した，血圧上昇措置で脳波が改善したRINDの2 例は安静時血圧が低かった症例であるが，これらもバイパ ス術により脳波の改善が得られている。ただし，1例はそ の後塞栓症による再発作を生じた。このように，血圧上昇 措置で脳波が改善した症例ではなんらかの方法で脳血流の 増加をはかることにより脳機能の改善を得ることができた. しかし, 塞栓症においてはその後再開通や再発作により再 び悪化する可能性もあり，これらの予測は困難である.

血圧下降措置を行った症例中 major strokeの 1 例は安 静時血圧が高かったためであり, minor stroke 例は臨床症 状がごく軽度でそれ以上の症状改善よりも再発作の防止が 優先された症例である。そして，脳波が血圧下降に伴い悪 化しバイパス術を施行した症例では術後再発作を生じてい ない. 保存的治療例においては 1 例ではあるが再発作で死 亡している，すなわち, hemodynamic crisis の可能性を判 定できる優れた方法である。たたし，臨床症状の厳重な監 視とともに経時的な脳波の分析が必要で，患側にわずかで も脳波の悪化傾向がみられたらその時点で血圧下降を中止 しなければならない. 血圧下降の範囲は経験的に決めたも のであるが，段階的に徐々に降圧し脳波を on-line 処理で 連続的に監視していけば脳機能が悪化しても subclinical なレベルでとどめることができる. 非虚血部の脳血流自動 調節能の閾值を下回るほど血圧を低下させると虚血巣のみ ならず非虚血部の脳機能低下ももたらすことになり危険で ある。

以上のように我々の方法はバイパス術適応症例の選択に 有用である。ただし，今回の対象例においては血圧変化に 伴う脳血流量の変化を同時に測定していない. 現在, positron emission tomography (PET)を用いて脳波記録と ともに脳血流量の測定を行っている。この結果については いずれ報告する予定である.

\section{結 語}

脳主幹動脈閉塞または狭窄症における脳機能回復性や hemodynamic crisis の可能性判定を，血圧上昇措置または 下降措置に伴う脳波変化を分析することにより行った。そ の結果，バイパス術施行例では術前の脳波分析から予測し た術後経過をたどった。 したがって, 我々の方法はバイパ 又術適応症例の選択に有用である.

脳波の記録分析に関して吉岡喜美雄氏に，本論文作成に関して 油谷敏子嬢に深謝いたします。 


\section{文献}

1) Ito Z, Suzuki A, Hen R, et al: Neurological Surgery, Excerpta Medica, Amsterdam, 1978, pp 233-239

2) Ito Z, Suzuki A: Microsurgery for Cerebral Ischemia, Springer-Verlag, New York, 1980, pp 117-122

3) Schmiedek P, Gratzl O, Spetzler R, et al: Selection of patients for extra-intracranial arterial bypass surgery based on rCBF measurements. J Neurosurg 44: 303, 1976

4）鈴木明文，伊藤善太郎：閉塞性脳血管障害に㧈ける機能回 復性の検討。臨床脳波 21: 20-28, 1979

5) Suzuki A, Ito Z, Yasui N: Cerebral Ischemia-An update, Excerpta Medica, Amsterdam, 1983, pp 191-201

6）鈴木明文, 安井信之, 吉岡喜美雄, ほか：波形認識法によ る脳波周波数二次元表示. 臨床脳波 26: 652-658, 1984

7) Suzuki A, Yasui N, Ohta H, et al: Microsurgical Anastomoses for Cerebral Ischemia, IGAKU-SHOIN, New York, 1985, pp 17-21
8) Suzuki A, Yasui N, Yoshioka K, et al: Topographical display of the peak frequency and percentage time of EEG. Electroenceph Clin Neurophysiol 61: S97, 1985

9) Suzuki A, Yoshioka K, Yasui N: EEG Topography 1986, NEURON, Tokyo, 1986, pp 215-229

10）鈴木明文：脳卒中一最新の臨床，医歯薬出版，東京，1989, pp 343-357

11) The EC/IC Bypass Study Group: The international cooperative study of extracranial/intracranial arterial anastomosis (EC/IC Bypass Study): Methodology and entry characteristics. Stroke 16: 397-406, 1985

12) The EC/IC Bypass Study Group: Failure of extracranialintracranial arterial bypass to reduce the risk of ischemic stroke. Results of an international randomized trial. N Engl J Med 313: 1191-1200, 1985

13）上野照剛，松岡成明：徐波を示す異常脳波の抽出とその表 示法. 医用電子と生体工学 14: 118-124, 1976

14）安井信之，鈴木明文，佐山一郎：閉塞性脳血管障害の治療, 現代医療社，東京，1989, pp 83-96 